\title{
養浜土砂が 2 次元海浜断面地形に与える影響 に関する実験的研究 EXPERIMENTAL STUDY ON EFFECT OF VARIOUS GRAIN SIZE FOR BEACH NOURISHMENT
}

\author{
澁谷容子 1 ・八尾規子 2 ・砂後聡子 $3 \cdot$ 松原雄平 $4 \cdot$ 黑岩正光 ${ }^{5}$ \\ Yoko SHIBUTANI, Noriko YAO, Satoko ISAGO, \\ Yuhei MATSUBARA, and Masamitsu KUROIWA
}

\author{
1正会員 博 (工) 日本学術振興会特別研究員PD (鳥取大学) (产 680-8552鳥取市湖山町南4-101) \\ 2学生会員 鳥取大学大学院 工学研究科 (下 680-8552 鳥取市湖山町南4-101) \\ 3 京都府警 \\ 4正会員 工博 鳥取大学教授 大学院工学研究科 (广 680-8552 鳥取市湖山町南4-101) \\ 5 正会員 博 (工) 鳥取大学准教授 大学院工学研究科 (广 680-8552 鳥取市湖山町南4-101)
}

\begin{abstract}
Recently, coarser sand nourishments have been noticed as effective defense works against beach erosion. In this study, laboratory experiments were conducted on the performance of beach nourishment of three types of grain size sand on a fine sand beach $\left(d_{50}=0.23 \mathrm{~mm}\right)$. The median grain sizes of the nourished sand are $d_{50}=0.23 \mathrm{~mm}, 0.70 \mathrm{~mm}$ and $3.75 \mathrm{~mm}$. The nourished sands were placed at near breaking point. After that the three types of irregular wave were acted. The waves were introduced, such as the erosion type, the accretion type and intermediated type condition. The wave types were selected by $C$ parameter suggested by Sunamura and Horikawa (1974). The changes of the beach profile were measured.
\end{abstract}

Key Words : Beach nourishment, Cross-shore sand, Coarse sand

\section{1 .はじめに}

海岸侵食対策として , 養浜工法などのソフト的 な対策が施されることが多くなっている．最近では 礫材 (粒径 3〜 15mm) を養浜材に用いることで， 根固め機能を発揮し砂浜が安定したという報告がな されている $\left(\right.$ 松浦ら ${ }^{1)}$, 古谷ら $\left.{ }^{2)}\right)$. また, 養浜 を行う場合，他から土砂を運び入れるのではなく， 同じ流砂系の港湾や河口に堆積した浚渫土砂を海上 輸送し，侵食域の沖合に土砂投入されることもしば しばである.このような状況から田中ら ${ }^{3), 4)}$ は沖合 養浜工法の検討を，浅野ら ${ }^{5}$ は陸上養浜の検討を光 れ光れの室内実験により行っている．さらに，宇多 ら ${ }^{6)}$ は現地実験においてナローマルチビームを用い て養浜土砂の動きを把握する試み行っている.養浜 砂の粒径が大きいと侵食を緩和する効果があること や沖合養浜を行うことで, 養浜材が潜堤のような役 割をし，汀線が前進することなどが明らかになって きている．また，澁谷ら ${ }^{7}$ は養浜砂がどのように移 動するのかという観点から 2 次元移動床実験を行っ ている.しかし, 養浜後の詳細な地形変化は不明で あり, 養浜土砂量や位置, 養浜砂の粒径の違いによ
る影響など多くの検討課題が残されている．とこで， 本研究では, 2 次元波動水槽を用いた移動床実験に よって養浜砂の粒径や量および養浜位置が 2 次元海 浜断面地形に与える影響を実験的に明らかにするも のである .

\section{2 . 実験装置および実験条件}

長さ $25 \mathrm{~m}$, 幅 $0.6 \mathrm{~m}$, 深さ $1.0 \mathrm{~m}$ の 2 次元断面水槽 の一端に $1 / 10$ 勾配の固定床の上に移動床 (中央粒 径 $d_{50}=0.23 \mathrm{~mm}$ の硅砂を層厚 $15 \mathrm{~cm}$ 敷き詰めた）を 設置し，不規則波を作用させ実験を行った . 水深は $0.6 \mathrm{~m}$ とし，実験装置の概要を図-1に示す．

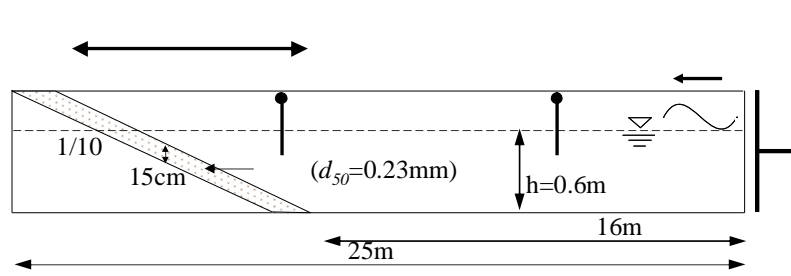

図-1 実験水槽（断面図） 
本実験では海浜断面形状が侵食型，中間型および 堆積型となる樣に不規則波浪条件を決定した . 海浜 断面の区分は Sunamura and Horikawa ${ }^{8)}$ による無次 元パラメータCによった .

$$
C=\frac{H o / L o(\tan \beta)^{0.27}}{\left(d_{50} / L o\right)^{0.67}}
$$

ここに，Ho/Lo は沖波の波形勾配， $\tan \beta$ は初期の海 底勾配， $d_{50}$ は底質の中央粒径である。

用いた波浪条件および，設置した移動床の粒径 $\left(d_{50}=0.23 \mathrm{~mm}\right)$ に対する $C$ パラメータを表- 1 に示 す.また, Sunamura and Horikawa により提案され ている無次元パラメータ $C$ と平衡断面地形の関係 を表-2に示す．

表- 1 波浪条件

\begin{tabular}{|c|c|r|r|}
\hline & 侵食型 & 中間型 & 堆積型 \\
\hline$H o(\mathrm{~cm})$ & 8.62 & 6.43 & 4.43 \\
\hline$T(\mathrm{~s})$ & 0.87 & 1.58 & 1.70 \\
\hline$C$ & 12.06 & 6.08 & 3.99 \\
\hline
\end{tabular}

表- 2 無次元係数 $C$ と平衡断面地形の関係

\begin{tabular}{|c|c|c|c|}
\hline & 侵食型 & 中間型 & 堆積型 \\
\hline 室内 & $C>8$ & $8>C>4$ & $4>C$ \\
\hline 現地 & $C>18$ & $18>C>9$ & $9>C$ \\
\hline
\end{tabular}

地形变化はレーザー変位計を用いて計測するとと もに，遡上域に設置した定点カメラの画像から， バームの幅，高さおよび汀線変化を読み取った .

図-2 に示すように, 汀線からバーム頂部までの距 離をバーム頂点位置 $L_{a}$, 汀線からバーム後方の初 期断面との交点までの距離をバーム幅 $L_{b}$, 静水面 からバーム頂点までの高さをバーム高 $z$ とした .

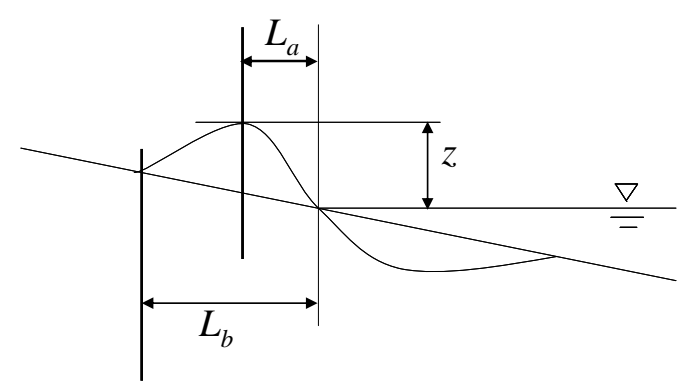

図- 2 バームの概要

\section{3 . 実験内容と結果}

本研究では養浜土砂か地形変化に与える影響や養 浜材の違いが炎の後の地形変化にどのような影響を 及ぼすかを検討するため, 大きく分けて以下の $2 つ$ の実験を行った .
（1）養浜砂の粒径および養浜の有無が遡上域に与え る影響について

初期状態の平行等深線断面に養浜を行い, 光れ攵 れの波浪を作用させ，養浜の有無および養浜砂の粒 径や養浜位置の違いか地形变化に及ぼす影響を調べ た。養浜材には中央粒径 $0.23 \mathrm{~mm} ， 0.70 \mathrm{~mm}$ よび $3.75 \mathrm{~mm}$ の 3 粒径の砂を用い, 養浜は砕波帯より岸 側に $0.005 \mathrm{~m}^{3}$ (Case岸)，沖側に $0.005 \mathrm{~m}^{3}$ (Case沖 I ) および0.01 $\mathrm{m}^{3}$ (Case沖 II) の土砂を投入した . 土砂 投入位置は砕波点の岸側に養浜を行う場合，水深 $h=4 \mathrm{~cm}$ の地点とし, 砕波点の沖側に養浜を行う場合， 水深 $h=9 \mathrm{~cm}$ 地点とした (図-3).なお，ここでの 砕波点は目視で確認した平均的な砕波点とする．ま た，養浜土砂は水と砂を混合し，あらかじめ間隙空 気を抜き, 土砂投入する際には水平方向に平行な形 状になるよう水面から静かに自由落下させた .

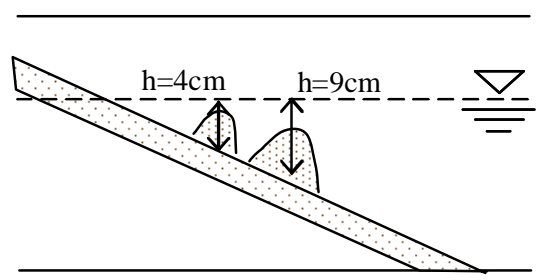

図- 3 養浜位置

図-4および図-5に各波浪条件および各養浜砂の粒 径に対するバーム幅およびバーム高の時間的変化を 示す . 図中の凡例は養浜砂の中央粒径を示し, 凡例 の左端に設置した移動床 $\left(d_{50}=0.23 \mathrm{~mm}\right)$ に対する 波浪条件を示す . 図-4より養浜砂の粒径の大きさ， 養浜位置や波浪条件に関わらず，養浜を行わない場 合，バーム幅は一番大きくなった . バーム高は設置 された移動床と同じ粒径の砂 $\left(d_{50}=0.23 \mathrm{~mm}\right)$ を養 浜した場合が一番高くなる結果となった（図-5)． また, 波浪作用開始から 1 時間後までは養浜土砂量 によってバームの成長具合が若干異なるが, 弚れ以 降は大きな違いはみられない (図-4(b)，(c)および 図-5(b)，(c) ) . 図-4および図-5を波浪条件別に見 ると，侵食型波浪 (図中青線) および中間型波浪 (図中黄緑線) 作用下では, 養浜の有無および養浜 砂の粒径の違いによるバームの形成過程に違いはみ られない。しかし, 堆積型波浪 (図中赤線) 作用下 においては, 養浜砂の粒径によりバームの形成過程 に違いか認められ，養浜砂の粒径が大きいとバーム 高は小さくなるっている (図-5) . 図-6に堆積型波 浪下において中央粒径 $0.23 \mathrm{~mm}$ および $3.75 \mathrm{~mm}$ の砂を 砕波点の沖に $0.01 \mathrm{~m}^{3}$ 養浜した場合 (Case沖II) の断 面地形の時間的変化の例を示す. 養浜材に小さい粒 径のものを用いると, 養浜砂が移動しやすく, バー ムの成長に寄与していることがわかる (図-6(a)) . 逆に大きな粒径の砂は移動しにくいため, 養浜位置 に留まり，バームの成長が遅いことが確認できる (図-6(b)). 

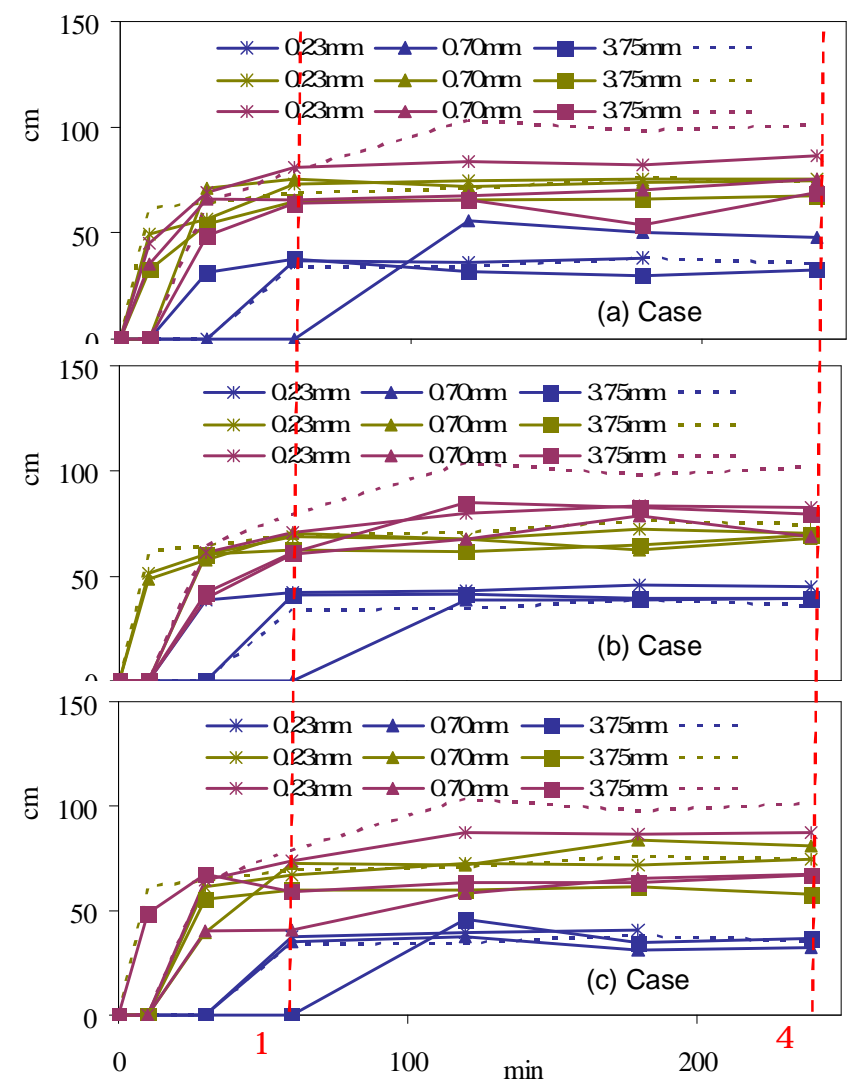

図-4 バーム幅の時間的変化
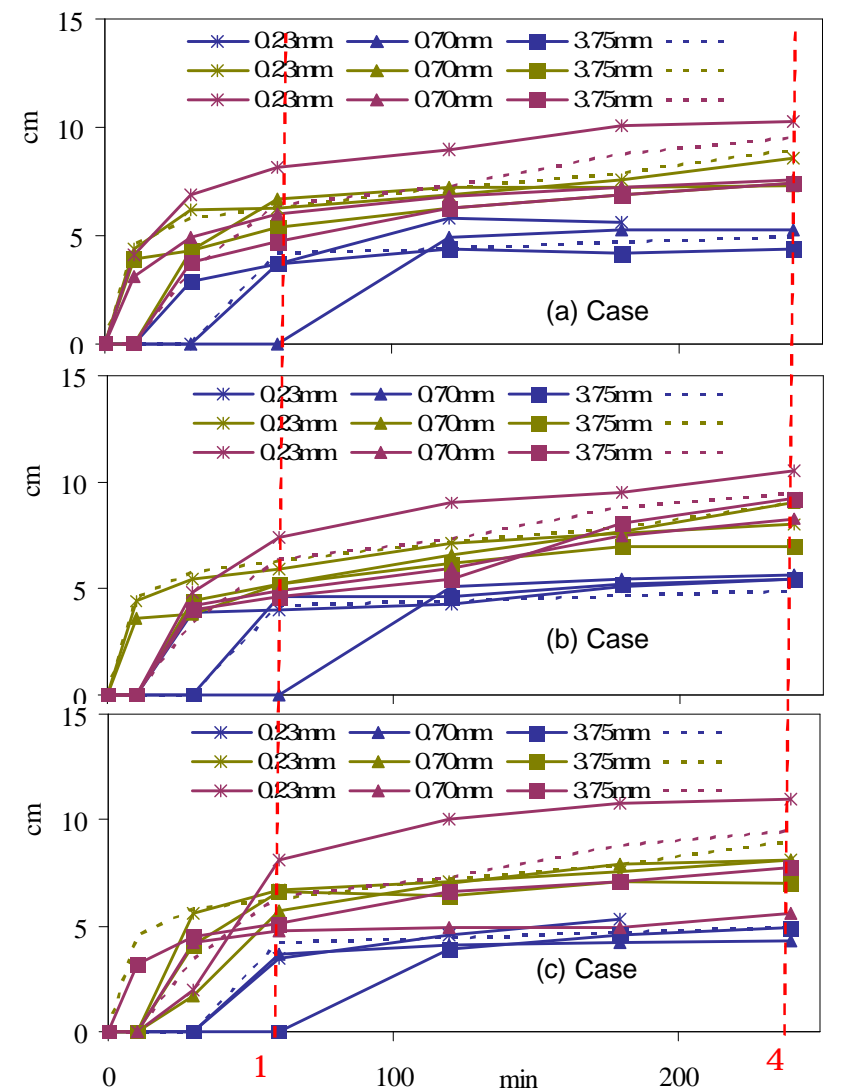

図- 5 バーム高の時間的変化

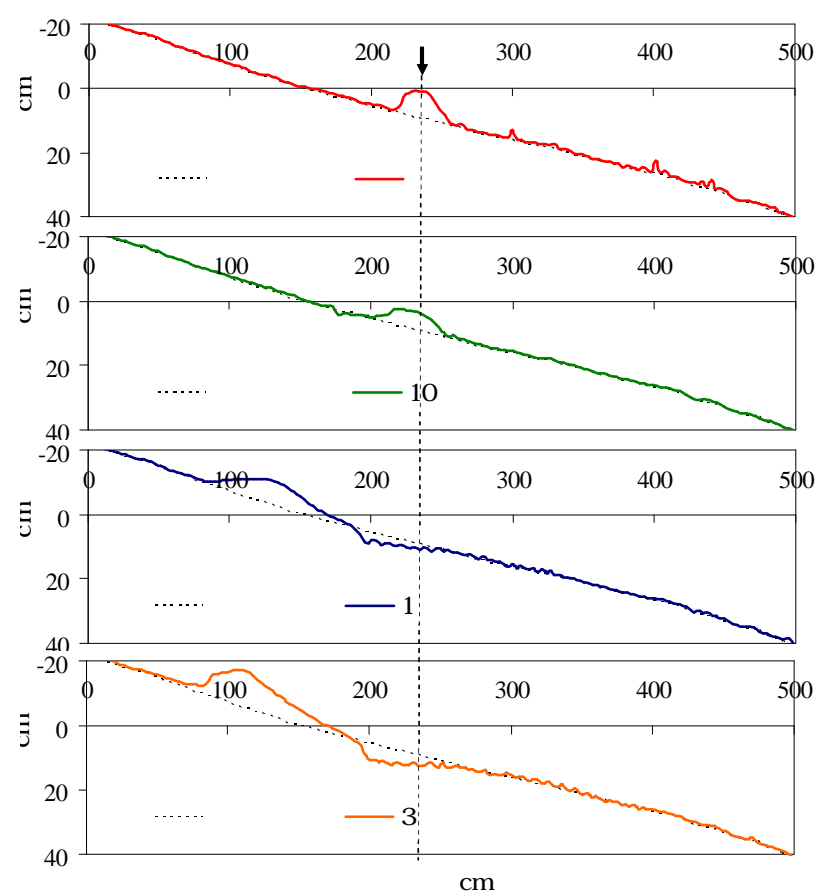

(a) 中央粒径 $0.23 \mathrm{~mm}$ 砂養浜
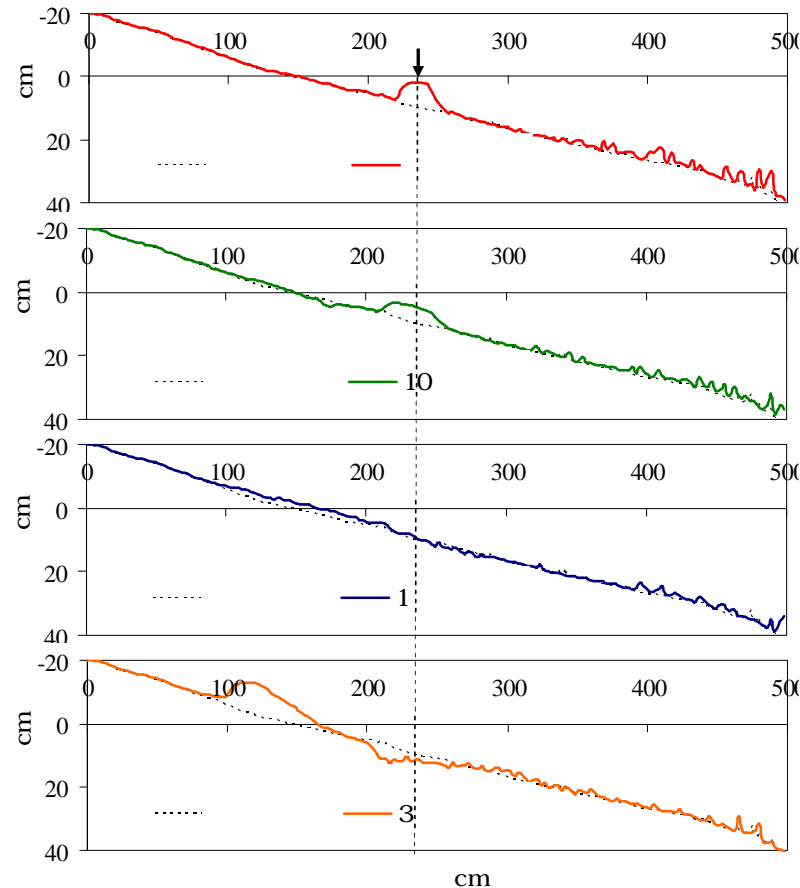

(b) 中央粒径 $3.75 \mathrm{~mm}$ 砂養浜

図- 6 堆積型波浪下における養浜後の地形変化

(Case沖 II) 
図-7に侵食型波浪下において養浜した場合 (Case 沖II ) の断面地形の時間的変化を示す. 図- 7(a) よ り養浜砂の中央粒径が小さいと侵食型波浪の作用に より養浜土砂が沖に運ばれている樣子がわかる．中 央粒径 $0.70 \mathrm{~mm}$ の砂を養浜した場合, 養浜砂が養浜 位置に留まっていること，一方 $3.75 \mathrm{~mm}$ を養浜材に 用いた場合は養浜土砂が岸側に運ばれている樣子が 確認できる．3.75mmの砂を養浜材に用いた場合， 逆上域にバームが形成されていることも確認できる．

図-8に各波浪条件および養浜砂の粒径に対する汀 線の時間的変化を示す. 汀線变化は初期状態の汀線 位置を原点とし沖方向の変化量を正とする .ほぼ全 てのケースにおいて, 養浜を行った場合, 養浜を行 わなかった場合よりも汀線が前進する結果となった . 特に侵食型 (図中青線) では養浜を行わなかった場 合, 波浪作用開始から 4 時間後, 汀線は後退してい るが, 養浜を行うことで汀線の後退を緩和させる結 果が得られた . さらに, 養浜材に粒径の大きなもの を用いた方が汀線の後退をより緩和させていること か確認できる.よって粗粒材養浜は汀線付近の侵食 を緩和させる直接的な機能を有していると考えられ る.また, 養浜土砂量の違いは汀線変化量の差に比 例していることが確認された (図-8(b)および(c)) .

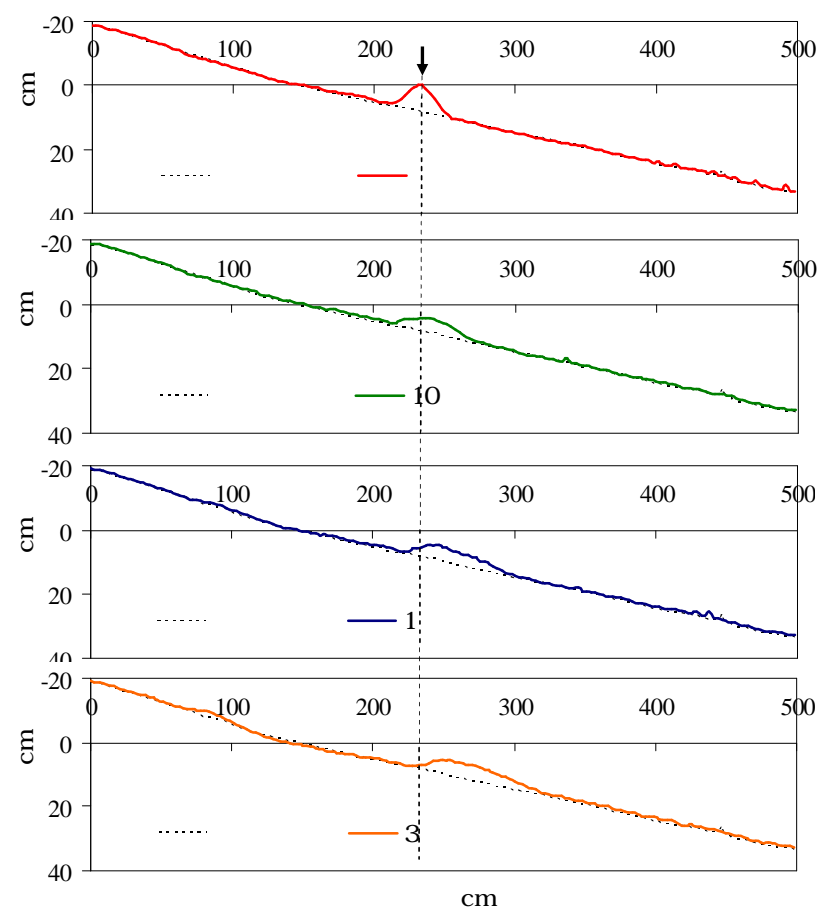

(a) 中央粒径 $0.23 \mathrm{~mm}$ 砂養浜

図- 7 侵食型波浪下における養浜後の地形変化

(Case沖 II)

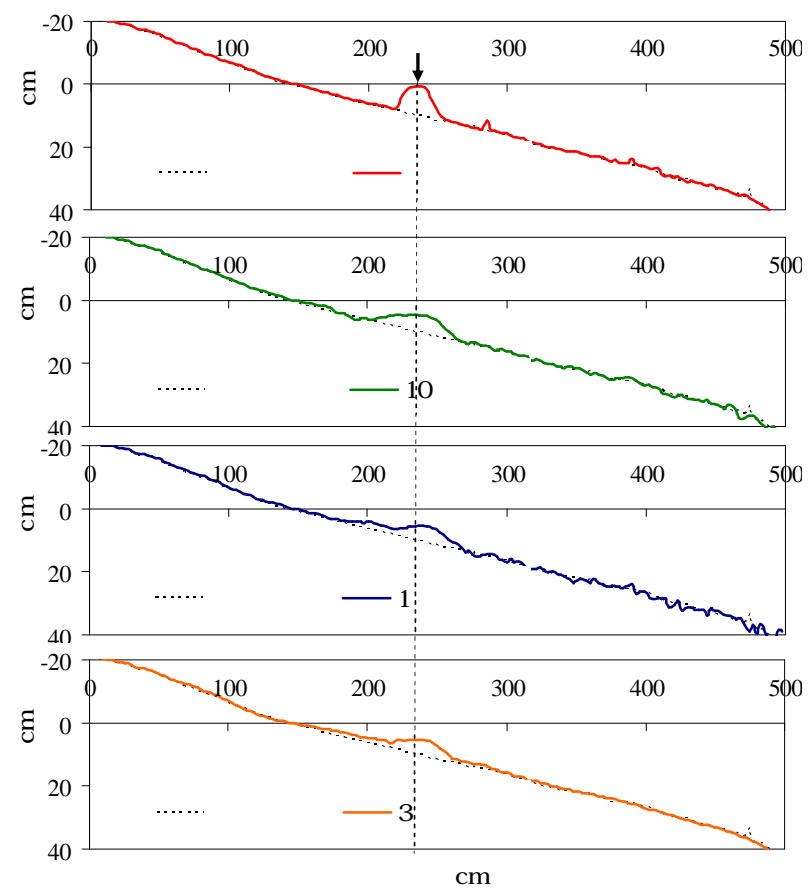

(b) 中央粒径 $0.70 \mathrm{~mm}$ 砂養浜

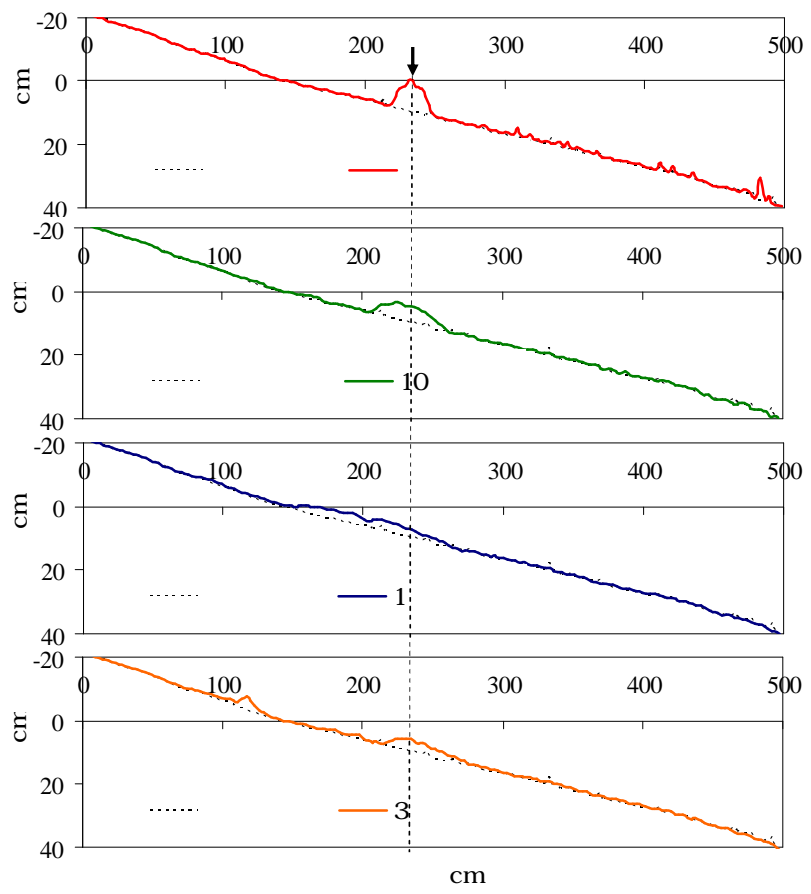

（c）中央粒径 $3.75 \mathrm{~mm}$ 砂養浜

図- 7 侵食型波浪下における養浜後の地形変化 (Case沖 II) 


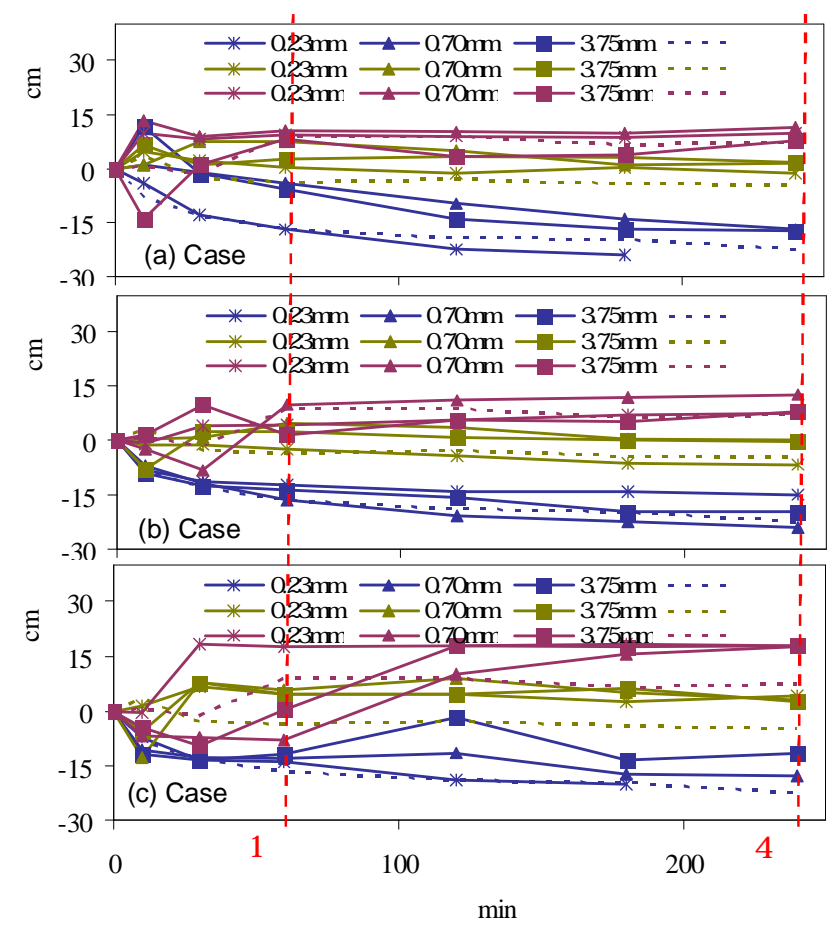

図- 8 汀線の時間的変化

（2）侵食性海岸に対する養浜効果について

侵食性海岸に対する養浜効果を検討するため，初 期断面に侵食型波浪を10時間作用させ，侵食型の平 衡海浜断面を形成させた . 光こに養浜を行い，再び 侵食型の波浪を作用させた . 養浜砂の粒径は(1) と 同樣に，中央粒径 $0.23 \mathrm{~mm} ， 0.70 \mathrm{~mm}$ おび $3.75 \mathrm{~mm} の$ 3 粒径とし，初期断面の侵食型波浪下の実験におい て粒径の違いが一番認められたCase沖Ｉ（砕波点の 沖側に0.01 $\mathrm{m}^{3}$ 土砂投入) の実験を行った .

図-9に侵食型の平衡断面地形に養浜を行い，再び 侵食型の波浪を作用させた場合の断面地形の時間的 変化を示す. 中央粒径 $0.23 \mathrm{~mm}$ の砂を養浜した場合， 波作用直後から養浜砂が拡散し10分後には投入地点 に土砂はほとんど残っていない (図-9(a) ) .一方， 養浜材に $3.75 \mathrm{~mm}$ の砂を用いた場合，投入地点に養 浜土砂が留まり， 3 時間後も養浜砂が投入地点に 残っていることが確認できる .

図-10に侵食型断面に養浜を行い侵食型の波浪を 作用させた場合の汀線の時間的変化を示す．侵食型 波浪下であっても養浜土砂が汀線前進に寄与してい る樣子がわかる . 浅野ら ${ }^{5}$ は養浜材の粒径に対する $C$ 值により波浪条件を分類できるとしていることか ら，図-11に養浜砂の粒径に対する $C$ 值を示す.設 置した移動床の粒径に対するC值は侵食型の波浪条 件であるが, 中央粒径が $3.75 \mathrm{~mm}$ の養浜砂に対するC 值は堆積型に分類されている．このことから，沖合 養浜を行った場合も養浜効果が持続している間は養 浜砂に対するC值で波浪条件を分類することが可能 であることがわかる

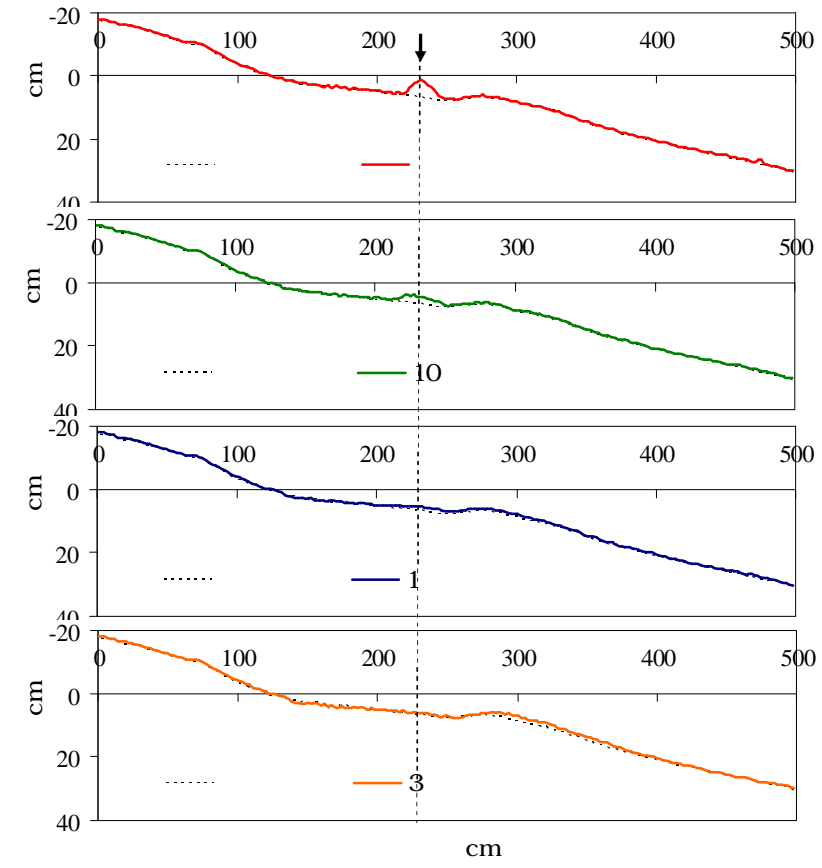

（a）中央粒径 $0.23 \mathrm{~mm}$ 砂養浜

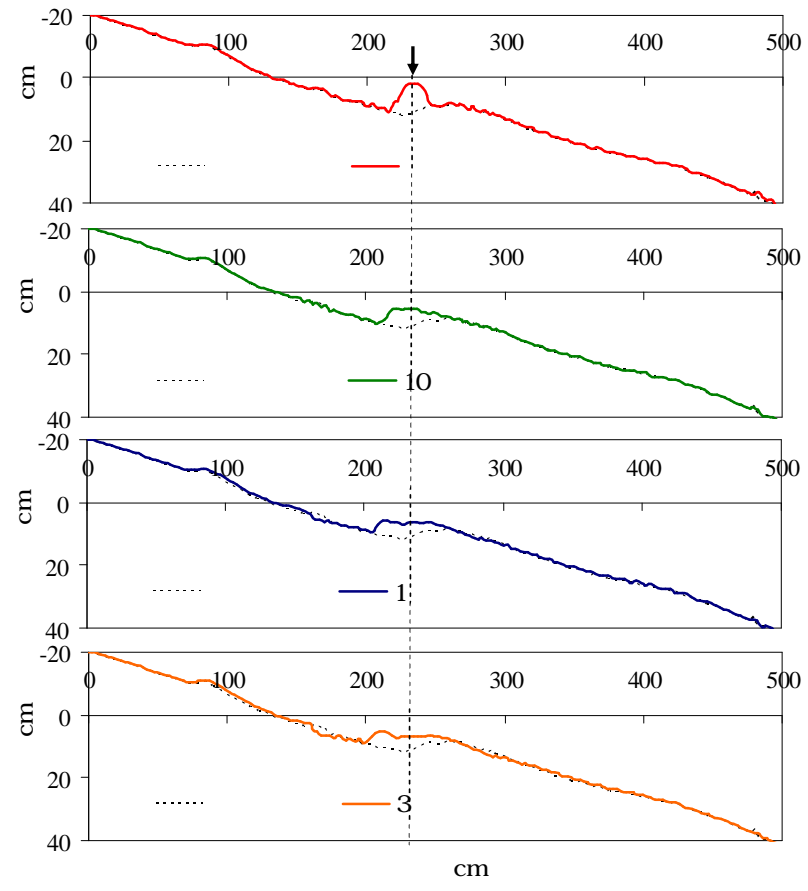

(b) 中央粒径 $3.75 \mathrm{~mm}$ 砂養浜

図- 9 侵食型断面における養浜後の地形变化 (侵食型波浪作用下)

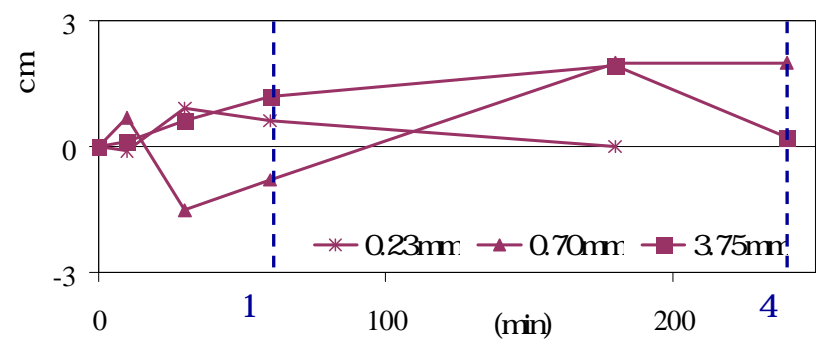

図-10 侵食型波浪下における養浜後の汀線変化 


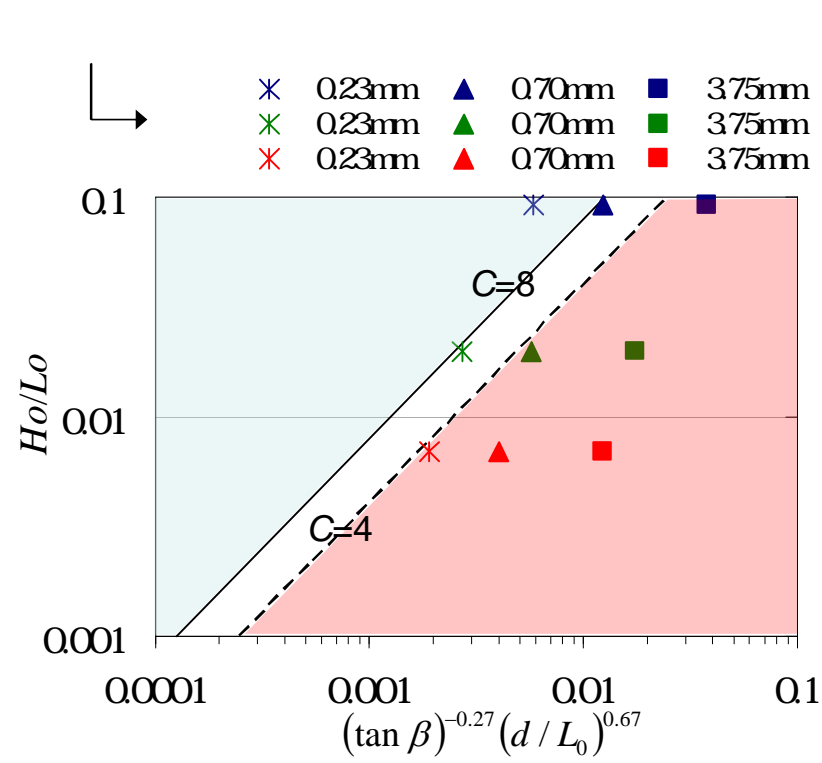

図- 11 養浜砂の粒径に対するC值

\section{4.おわりに}

本研究では, 養浜土砂の粒径や養浜位置および養 浜土砂量が兴の後の地形変化にどのような影響を及 ぼすのかを調べるため，2 次元移動床実験を行った． 得られた主な結果を以下に示す。

（1）養浜砂の粒径および養浜の有無が遡上域に与 える影響について

・中間型および侵食型波浪作用下においては, 養 浜の有無および養浜砂の粒径の大きさはバーム の成長に有意に影響しない .

・堆積型波浪作用下では, 養浜砂に粒径の小さい ものを用いると養浜土砂が動きやすく，バーム は成長する傾向を示す．

- 養浜砂の粒径の違いおよび養浜の有無は汀線変 化に大きく影響し，養浜砂の粒径が大きいほど 汀線の後退を緩和もしくは汀線の前進をもたら す.
（2）侵食性海岸に対する養浜効果について

- 養浜材に粗な粒径の砂を用いると, 養浜位置に 留まる時間が長く養浜効果は持続する。

- 沖合養浜時においても, 養浜砂の粒径に対する $C$ 值で波浪条件を分類することができる .

・侵食型波浪下においても，C值が堆積型に分類 されるような養浜材を用いることで，一時的に 堆積型波浪となり，汀線は前進する．

謝辞: 本研究は日本学術振興会特別研究員奨励費 (22・2128) の援助ならびに，国土交通省中国地方 整備局日野川河川事務所との共同研究の一部として 行われました .ここに記して感謝を表します．

\section{参考文献}

1) 松浦健朗, 宇多高明, 諏訪義雄, 山田浩次, 福本崇 嗣：砂浜の海岸保全施設指定にむけた粗粒材養浜の有 効性の検討，海洋開発論文集，第 25 巻，pp. 1119$1124,2009$.

2) 古谷真広, 小林昭男, 宇多高明, 野志保仁 : 明石海岸 における礫養浜後の海岸状況変化, 海洋開発論文集, 第 26 巻, pp. 1053 1057,2010 .

3)田中博通, 本田秀樹, 鈴木操, 川口達矢 : 潜堤式養浜 工法の検討，海岸工学論文集，第 53 巻，pp. 671-675， 2006.

4) 田中博通, 川口達矢, 本田秀樹, 鈴木操 : 沖合養浜工 法の断面実験に関する研究, 海洋開発論文集, 第 23 巻, pp. 1087-1091, 2007.

5) 浅野泰史, 佐藤壃司, 劉海江, 高川智博 : 粗粒径材を 用いた養浜の効果に関する実験的研究, 土木学会論文 集 B2 (海岸工学)，Vol.66, No. 1, pp. 631-635，2010.

6) 宇多高明, 田代洋一, 長山秀樹 : ナローマルチビーム 測量による沖合養浜時の土砂移動観測，海岸工学論文 集, 第 55 巻, pp. 776- $780,2008$.

7) 涉谷容子, 松原雄平, 黑岩正光, 八尾規子, 谷口隼 也 : 波浪条件が養浜土砂の移動に及ぼす影響と光の効 果に関する実験的研究, 海洋開発論文集, 第 26 巻, pp. 1047- 1052, 2010 .

8) Sunamura, T., and Horikawa, K. : Two-dimensional beach transformation due to waves, Proc. $14^{\text {th }}$ Int. Conf. on Coastal Engineering, pp.920-938, 1974. 